\title{
Organizational Identification and Psychological Contract Relationship between Public Employees
}

\author{
Ayhan Bayram and Ece Zeybek
}

\begin{abstract}
The aim of this research to determine which factors are affecting the relationship between psychological contract and to organizational identify in public employees.

In face to face interviews with 128 government employees were interviewed and easy research using sampling methods. After failing ones have screened a total of 123 surveys analyzed and subjected survey analysis. In order to measure the psychological contract by Millward and Hopkins (1998) it was developed by and by Mimaroğlu (2008) Turkish version, tested the validity and reliability of the psychological contract questionnaire was used. The scale consists of two dimensions. There are 17 items on the scale. By Mael and Ashforth to measure to organizational identification (1992) developed by Plug and by Aydemir (2004) Turkish version, the validity and reliability of the scale tested organizational identification was used. The scale consists of single sub-dimensions. There are 7 items in the scale. Kolmogorov-Smirnov test was determined to be in accordance with the normal distribution of data. Therefore, Mann-Whitney $U$ and Kruskal-Wallis $H$ test was used to compare variables which are the non-parametric tests.

Psychological contract and organizational identification shall gender, age and education variables vary and operational with relational dimensions between significant positive at the level of $22.2 \%(p=, 013<.05)$ was determined to be a very weak relationship.

Psychological contract and organizational identification levels may vary based on factors such as the personal perception, the severity of the expectations and beliefs towards the meeting. In the evaluation of the psychological contract and organizational identification levels of public employees, gender, age and education level should be taken into consideration and this work should be done by the developer.
\end{abstract}

Index Terms-Confusion, organizational productivity, relational and transactional.

\section{INTRODUCTION}

In recent years, the success of the organization, the environment, technology, many factors in addition to such policies, the relationships they establish with each of the members of the organization and nature of organizational commitment of this relationship is understood that concepts such as belonging scientific as possible by addressing. However, advances in technology, changing market conditions, the new management approach, factors such as increased competition, are complicating the structure of institutions, specialization increases, and are alienated from the consequences of the employees who both themselves and things, seen a decrease in their commitment to the organization. This results in the alienation of a substantial

Manuscript received January 25, 2016; revised February 27, 2016; accepted April 10, 2016.

The authors are with Istanbul Arel University, Turkey (e-mail: ayhan_bayram1987@hotmail.com.tr, ecezeybek@arel.edu.tr). part of the employees, it is observed that they leave their work places in the first year. In this case the employment contract signed in recruitment shows that employee commitment to the organization and to ensure sufficient to reduce the employee turnover rate.

Large-scale changes or transformations in the external environment of organizations, employees, and increased the importance of the psychological relationship between organizations. Nowadays all kinds of organizations take care about having a sense of loyalty and in some sense beyond expectations as to have the intention to leave the workplace. Organizations will want to adopt the criteria to identify the individual identity from organizations of employees [1].

\section{A. Psychological Contract}

Psychological contract is defined as consisting of an implicit expectation what the individuals on the basis of reciprocity between the organization itself and, assuming they comply with the norms of each other, unspoken unwritten agreement [2]. Schein put forth psychological contract as the individual employee and revealed the unspoken and unwritten mutual expectations between the whole organizations [3]. To create a psychological contract, the obligations of employees and employers are obliged to fulfill their faith to meet this obligation must be in balance. So, a healthy psychological contract is formed when the mutual expectations are met. As a result of this it develops organizational citizenship behavior so employees stay as a volunteer in business, or to contribute to the organization and dedication, motivation increases. If can not ensure the balance, employees both in terms of the deterioration of psychological health organizations, employment, absenteeism, reduction in contributions, such as inefficiency revealed negative results [4].

Psychological contracts can be defined in four flavors as high or low in terms of performance requirements and as looking to be short or long time in terms of scope [5]. These are transactional, temporary, balanced and relational.

1) Transactional Psychological Contract: Lawful relationship between work and wages "as expressed in transactional contracts, higher wages in hard work, money is the obligation of the employee is defined as taking turns high external as fast career growth [4].

2) Relational Psychological Contract: The contract which opposed of transactional psychological contract is based on social exchange. It includes larger period and some factors such as support, socio-emotional commitment [4].

Relational contracts include elements such as to support long-term job security, the career development and personal problems ([6]. 
3) Balanced Psychological Contract: It requires risks to be shared between the employee and the employer. In addition, a number of conditions, such as economic conditions and the labor needs of these types of agreements are expected reorganization of change when [7].

4) Temporary Psychological Contract: Temporary contracts are created during the termination of the employment relationship. Such contracts have little or performance requirements or no have. Members to the employment relationship has no binding obligations in the future. The employee benefits in such contracts is quite low and in case of continuation of the relationship of these benefit scan be expected to continue to decline [8].

\section{B. Organizational Identification}

Cheney (1983) according to the definition made by organizational identification; individuals they feel loyalty to the organization, that they are covered by high interest membership organization, with high fidelity and that they have the objective of the organization against organization is referred to as process values they share with other members of the organization. Also Scott and Lane was identified as the organization itself as a part feel psychologically to organizational identification. In this context, describing the psychological bond with the organization that runs the organization's distinguishing characteristics who define themselves as being established in the event of adoption [9].

Organizational identification, helps to increase the success of the institution with the corporate action was coordinated way. It is also possible to see as a convincing mechanism for participation in the organization's activities. It becomes a source of motivation for targets of individual and organizational goals to make further efforts for the realization of these goals [10].

\section{METHOD}

This part of the study, the data obtained as a result of the implementation of the survey on the relationship between public officials and the psychological contract describes the organizational identification through various statistical methods. In this study, psychological contract and determining their views about public officials working to identify organizational Recep Tayyip Erdogan Rize University; It aims to determine the relationship between psychological contract and organizational identification.

\section{A. Data Collection Tools}

In this study, data were collected using face-to-face survey. In the first part of the questionnaire, 6 questions were asked to determine the demographic characteristics of public employees. The second and third parts, psychological contract and is located phrase for measuring total of 24 to organizational identification. The respondents were asked to give a statement asked all answers appropriate to their situation.

The psychological contract questionnaire was developed to measure the psychological contract by Millward and
Hopkins (1998) and adapted to Turkish version by Mimaroglu which tested the validity and reliability of was used. The scale consists of two dimensions. There are 17 items on the scale.

To measure to organizational identification (1992) developed By Mael and Ashforth and adapted to Turkish version by Tak and by Aydemir (2004), the validity and reliability of the scale tested organizational identification was used. The scale consists of a single sub-dimensions. There are 7 items in the scale.

\section{B. The Scope of Research and Sampling}

The universe of the research staff at the University of Recep Tayyip Erdogan constitute public employees. Easy sampling was used in the sampling method based on probability sample of the research [11]. In face to face interviews with 128 government employees were interviewed and easy research using sampling methods. After failing ones have screened a total of 123 surveys analyzed and subjected survey analysis.

\section{Research Model}

Model of the study are shown in Fig. 1. Research models are given to the first elements of the psychological contract. After that, place to identify organizational, are trying to determine the relationship between organizational identification with the psychological contract.

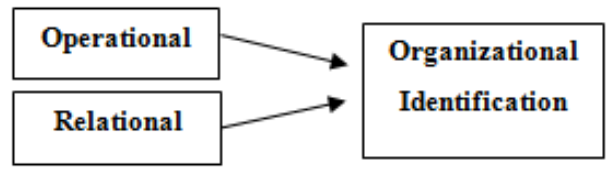

Fig. 1. Research model.

Located dimensions of psychological contract research model in Fig. 1 shows relation between transactional and relational factors effect to organizational identification.

\section{FINDINGS}

The reliability of the questionnaire prepared by Likert scale as measured by Cronbach's alpha reliability coefficient. According to the analysis Cronbach's Alpha value was found to be ,678. This value of $0,60 \leq \alpha<0,80$ value could be called in because of the scale is reliable [12]. In analyzing the data, the frequency is used as the standard deviation of the mean and descriptive statistics. While testing the hypothesis of the research, the relationship between the set and the model is appropriate to the size of a normal distribution of the data was examined.

Since factor analysis related to the scales used in this study was done before, it is not carried out again rather analysis with subscales as in the original scale was performed. Psychological contracts are measured under two dimensions, including transactional and relational. The organizational identification was measured under just one dimension. In the study, demographic characteristics of public employees regarding sex, age, marital status, education level, questions were asked regarding working hours and income. Demographic profile of the sample group in the light of the answers to these questions are shown in Table I. 
TABLE I: DEMOGRAPHIC INFORMATION ON THE SAMPLE GROUP

\begin{tabular}{|c|c|c|c|}
\hline Sex & Frequency & $\%$ Frequency & Mode \\
\hline Male & 76 & 61,8 & \multirow{2}{*}{1} \\
\hline Female & 47 & 38,2 & \\
\hline \multicolumn{3}{|l|}{ Age } & \multirow{5}{*}{1} \\
\hline 26-30 ages & 50 & 40,7 & \\
\hline $31-35$ ages & 40 & 32,5 & \\
\hline $36-40$ ages & 18 & 14,6 & \\
\hline 41 ages and upper & 15 & 12,2 & \\
\hline \multicolumn{3}{|l|}{ Marial Status } & \multirow{3}{*}{1} \\
\hline Married & 80 & 65 & \\
\hline Single & 43 & 35 & \\
\hline \multicolumn{3}{|l|}{ Education } & \multirow{5}{*}{3} \\
\hline High School & 15 & 12,2 & \\
\hline College & 19 & 15,4 & \\
\hline Undergraduate & 72 & 58,5 & \\
\hline Graduate education & 17 & 13,8 & \\
\hline \multicolumn{3}{|l|}{ Operation Time } & \multirow{5}{*}{1} \\
\hline 0-5 Years & 50 & 40,7 & \\
\hline 6-10 Years & 43 & 35 & \\
\hline 11-15 Years & 14 & 11,4 & \\
\hline 16 Years and upper & 16 & 13 & \\
\hline \multicolumn{3}{|l|}{ Income Status } & \multirow{4}{*}{2} \\
\hline $1000-2000 \mathrm{TL}$ & 21 & 17,1 & \\
\hline 2001-3000 TL & 80 & 65 & \\
\hline $3001 \mathrm{TL}$ and upper & 22 & 17,9 & \\
\hline
\end{tabular}

Table I examined when the majority of those surveyed were male $(61.8 \%), 26-30$ age range $(40.7 \%)$, married the marital status $(65 \%)$, degree of education $(58.5 \%)$, the operating time $0-5$ year range $(40.7 \%)$ and profitability of TL in the range 2001 to $3000(65 \%)$ appear to be.

About the scale before it is made by making the re-factor analysis, factor analysis of the scale is located in the original transactional, relational and organizational identification in order to determine whether the variable is normally distributed according to the Kolmogorov-Smirnov test was performed. Kolmogorov-Smirnov test result shows that the data fit a normal distribution. A total of 24 questions prepared by the variables that make up the multiscale Likert scale. Normal distribution test results related to the variables shown in Table II.

TABLE II: NORMAL Distribution TEST RESULtS REgaRDiNG VARIABLE

\begin{tabular}{|c|c|c|c|}
\hline & $\mathrm{N}$ & Statistic & $\mathrm{p}$ \\
\hline Transactional & 123 &, 115 &, 000 \\
\hline Relational & 123 &, 078 &, 062 \\
\hline $\begin{array}{c}\text { Organizational } \\
\text { Identification }\end{array}$ & 123 &, 128 &, 000 \\
\hline
\end{tabular}

When Table II is examined in all dimensions ( $p>.05$ ) seems not to be. $P$ value of transactional and organizational identification data are normally distributed, due to the small ,05 to. Therefore, in order to compare the variables (in case of 2 groups) of the non-parametric Mann-Whitney U test and (3 more groups and if) the Kruskal-Wallis $\mathrm{H}$ test. Significance difference was noted between those variables and demographic factors in the study are included. Hypothesis of the research is as follows:

H0: There is no difference between transactional and relational variables and the gender variable.

H1: There is a difference between transactional and relational variables and the gender variable.
H0: There is no difference between the age variable organizational identification variable.

H2: The age variable is the difference between organizational identification variable.

H0: Educational level operational variable, there is no difference between relational and organizational identification variables.

H3: Educational level operational variable, there are differences between relational and organizational identification variables.

H0: Operational factor increased perceptions of relational of the psychological contract size increases.

H4: Operational factor increased perceptions of relational does not increase the size of the psychological contract.

Mann-Whitney $U$ test results found significant difference in test results between the sexes with the operational and relational variables are shown in table III.

TABLE III: TEST RESULTS OF MANN-WHITNEY U ABOUT RELATIONAL and TRanSactional Variable With SeX Variable

\begin{tabular}{|c|c|c|c|c|c|}
\hline & Sex & $\mathrm{N}$ & $\begin{array}{c}\text { Rank Value } \\
\text { Average }\end{array}$ & $\mathrm{Z}$ & $\mathrm{P}$ \\
\hline \multirow{2}{*}{ Transactional } & Male & 76 & 66,98 & \multirow{2}{*}{$-1,978$} & \multirow{2}{*}{,048 } \\
\hline & Female & 47 & 53,95 & & \\
\hline \multirow{2}{*}{ Relational } & Male & 76 & 68,59 & \multirow{2}{*}{$-2,618$} & \multirow{2}{*}{,009 } \\
\hline & Female & 47 & 51,35 & & \\
\hline
\end{tabular}

Table III located Mann-Whitney U Test results according to $(0.05$ significance level) between gender and operational variables $(p=, 048<.05)$ was found to be a significant difference. The average order value of operational variables, seems to be higher than that of men and women.

Between relational variables of gender $(p=, 009<.05)$ was found to be a significant difference. The average order value of relational variables, seems to be higher than that of men and women.

Gender and organizational identification $(p=, 134>, 05)$ carried out between variables found no significant difference in the Mann-Whitney U test.

Kruskal-Wallis $\mathrm{H}$ test results found significant difference in age between organizational identification variable test results shown in Table IV.

TABLE IV: KRUSKAL-WALLIS H TEST RESULTS RELATED TO ORGANIZATIONAL IDENTIFICATION VARIABLES WITH AGE.

\begin{tabular}{|l|c|r|r|r|r|}
\hline & Age & $\mathrm{N}$ & $\begin{array}{c}\text { Rank Value } \\
\text { Average }\end{array}$ & $\chi^{2}$ & $p$ \\
\hline \multirow{4}{*}{$\begin{array}{l}\text { Organizational } \\
\text { Identification }\end{array}$} & $26-30$ ages & 50 & 59,67 & & \\
\cline { 2 - 5 } & $31-35$ ages & 40 & 67,16 & \multirow{2}{*}{10,879} &, 012 \\
\cline { 2 - 5 } & $36-40$ ages & 18 & 41,78 & & \\
\cline { 2 - 5 } & 41 ages and upper & 15 & 80,27 & & \\
\hline
\end{tabular}

Table IV situated by the Kruskal-Wallis $\mathrm{H}$ Test results (0.05 significance level) with organizational identification variable age $(p=, 012<.05)$ was found to be a significant difference between variables. The average value of a variable of organizational identification as well, of those in the age range $36-40$, seems to be lower than those contained in the other groups.

Transactional $(p=, 183>, 05)$ and relational variable $(p=, 564>, 05)$ made a significant difference in results between age variables Kruskal-Wallis $\mathrm{H}$ test was found.

The Kruskal-Wallis $\mathrm{H}$ test conducted for determining the significant differences that indicate which age group stems 
from the differences in organizational identification variable Mann Whitney $\mathrm{U}$ test results are shown in Table $\mathrm{V}$.

TABLE V: AGE AND ORGANIZATIONAL IDENTIFICATION ON THE MANNWHITNEY U TEST RESULTS VARIABLE

\begin{tabular}{|c|c|c|c|c|c|}
\hline & Age & $\mathrm{N}$ & $\begin{array}{c}\text { Rank Value } \\
\text { Average }\end{array}$ & $\mathrm{Z}$ & $\mathrm{P}$ \\
\hline \multirow{4}{*}{$\begin{array}{c}\text { Organization } \\
\text { al Identification }\end{array}$} & $31-35$ & 40 & 33,60 & \multirow{2}{*}{$-2,774$} & \multirow{2}{*}{, 006} \\
\cline { 2 - 5 } & $36-40$ & 18 & 20,39 & & \multirow{2}{*}{$-3,310$} \\
\cline { 2 - 5 } & $\begin{array}{c}41 \text { and } \\
\text { upper }\end{array}$ & 15 & 23,001 & & \\
\cline { 2 - 5 } & & 18 & 11,94 & & \\
\hline
\end{tabular}

Table $\mathrm{V}$ situated by the Mann-Whitney $\mathrm{U}$ test results (0.05 significance level) differences between age variable with organizational identification, age range 36-40 and 3135 age range $(p=, 006<.05)$ and 36-40 years 41 and over age range $(p=.001<.05)$ were among the participants at the interval and there is a difference in the level of participation points. Age variable with organizational identification, the significant difference between variables was determined that due to the participants in the 36-40 age range.

The Mann-Whitney $U$ test between variables marital status, relational $(p=, 277>, 05)$, operational $(p=, 471>, 05)$ and organizational identification $(p=, 802>, 05)$ of significant differences could not be found.

Kruskal-Wallis $\mathrm{H}$ test results found significant differences in the operational training conditions, the test results between relational and organizational identification variables are shown in Table VI.

TABLE VI: KRUSKAL WALLIS H TEST RESULTS OF BETWEEN EDUCATION AND TRANSACTIONAL, RELATIONAL AND ORGANIZATIONAL

\begin{tabular}{|c|c|c|c|c|c|}
\hline & Education & $\mathrm{N}$ & $\begin{array}{c}\text { Rank Value } \\
\text { Average }\end{array}$ & $\chi^{2}$ & $\mathrm{P}$ \\
\hline \multirow{4}{*}{ Transactional } & High School & 15 & 81,20 & \multirow{4}{*}{12,476} & \multirow{4}{*}{,006 } \\
\hline & College & 19 & 67,50 & & \\
\hline & Undergraduate & 72 & 62,17 & & \\
\hline & Graduate education & 17 & 38,21 & & \\
\hline \multirow{4}{*}{ Relational } & High School & 15 & 88,30 & \multirow{4}{*}{12,043} & \multirow{4}{*}{, 007} \\
\hline & College & 19 & 67,16 & & \\
\hline & Undergraduate & 72 & 58,49 & & \\
\hline & Graduate education & 17 & 47,88 & & \\
\hline \multirow{4}{*}{$\begin{array}{l}\text { Organizational } \\
\text { Identification }\end{array}$} & High School & 15 & 74,63 & \multirow{4}{*}{14,092} & \multirow{4}{*}{, 003} \\
\hline & College & 19 & 79,89 & & \\
\hline & Undergraduate & 72 & 52,02 & & \\
\hline & Graduate education & 17 & 73,13 & & \\
\hline
\end{tabular}

Table VI situated by the Kruskal-Wallis $\mathrm{H}$ Test results (0.05 significance level) with the operational level of education variable $(p=, 006<.05)$ was found to be a significant difference between variables. The average order value of operational variables, the case of secondary education, higher than those contained in other groups, and those with postgraduate training in case seems to be lower than those contained in the other groups.

Education case with relational variable $(p=, 007<.05)$ was found to be a significant difference between variables. The average order value of relational variables, which in case of secondary education, seems to be higher than those contained in the other groups.

Education variable by organizational identification $(p=, 003<.05)$ was found to be a significant difference between variables. The average value of a variable of organizational identification sequence, which is the case of undergraduate education is considered to be lower than those contained in the other groups.

The Kruskal-Wallis $\mathrm{H}$ test showing significant differences in the transactional, relational and organizational identification of structures of differences in the variables that determine which stems from education groups Mann-Whitney U-test results are shown in Table VII.

TABLE VII: ANN WHITNEY U TEST RESULTS OF BETWEEN EDUCATION AND TRANSACTIONAL, RELATIONAL AND ORGANIZATIONAL IDENTIFICATION

\begin{tabular}{|c|c|c|c|c|c|}
\hline & Education & $\mathrm{N}$ & $\begin{array}{c}\text { Rank } \\
\text { Value } \\
\text { Average }\end{array}$ & $\chi^{2}$ & $\mathrm{P}$ \\
\hline \multirow{8}{*}{ Transactional } & High School & 15 & 55,73 & \multirow{2}{*}{$-1,988$} & \multirow{2}{*}{, 047} \\
\hline & Undergraduate & 72 & 41,56 & & \\
\hline & High School & 15 & 21,77 & \multirow{2}{*}{$-2,991$} & \multirow{2}{*}{, 003} \\
\hline & Graduate education & 17 & 11,85 & & \\
\hline & College & 19 & 22,61 & \multirow{2}{*}{$-2,483$} & \multirow{2}{*}{, 013} \\
\hline & Graduate education & 17 & 13,91 & & \\
\hline & Undergraduate & 72 & 48,44 & \multirow{2}{*}{$-2,596$} & \multirow{2}{*}{, 009} \\
\hline & Graduate education & 17 & 30,44 & & \\
\hline \multirow{4}{*}{ Relational } & High School & 15 & 61,67 & \multirow{2}{*}{$-2,992$} & \multirow{2}{*}{, 003} \\
\hline & Undergraduate & 72 & 40,32 & & \\
\hline & High School & 15 & 22,00 & \multirow{2}{*}{$-3,133$} & \multirow{2}{*}{, 002} \\
\hline & Graduate education & 17 & 11,65 & & \\
\hline \multirow{6}{*}{$\begin{array}{l}\text { Organizational } \\
\text { Identification }\end{array}$} & High School & 15 & 57,70 & \multirow{2}{*}{$-2,319$} & \multirow{2}{*}{, 020} \\
\hline & Undergraduate & 72 & 41,15 & & \\
\hline & College & 19 & 61,87 & \multirow{2}{*}{$-2,956$} & \multirow{2}{*}{, 003} \\
\hline & Undergraduate & 72 & 41,81 & & \\
\hline & Undergraduate & 72 & 42,06 & \multirow{2}{*}{$-2,214$} & \multirow{2}{*}{, 027} \\
\hline & Graduate education & 17 & 57,44 & & \\
\hline
\end{tabular}

According to the test result of Mann-Whitney $U$ in Table VII (difference between the 0.05 significance level) education with transactional variable degree with high $(p=, 047<, 05)$, graduate high school $(p=, 003<.05)$ graduate and undergraduate $(p=, 013<.05)$ and graduate with a bachelor's degree $(p=, 009<.05)$ were among the participants in the case and there is a difference in the education level of participation points. Education status was determined that variable with a significant difference between transactional and variable due to the participants in the case of graduate school education.

The difference between education and relational variables, license high school $(p=, 003<.05)$ and graduate with a high school $(p=, 002<.05)$ were among the participants in educational attainment and there is a difference in the level of participation points. Education status was determined that due to the participants in the event of significant differences between the variables of school education with relational variables.

The difference between education and organizational identification variable degree with high $(p=, 020<.05)$, license undergraduate $(p=, 003<.05)$ and graduate with a bachelor's degree $(p=, 027<.05)$ in the case of education There is a difference between the participants and the level of participation points. Educational level is variable and is determined to result from the participants in the event of significant differences between the degrees of organizational identification variable. 
Transactional $(p=, 201>, 05)$, relational $(p=, 604>, 05)$ and organizational identification $(p=, 397>, 05)$ variable between carried out between working time variables Kruskal-Wallis $\mathrm{H}$ significant difference in the outcome test was found.

Income status varuable and between transactional $(p=, 789>, 05)$, relational $(p=, 135>, 05)$ and organizational identification $(p=, 701>, 05)$ variable carried out between variables Kruskal-Wallis $H$ significant difference in the outcome test was found.

Because of valuables have not shown normal distribution between transactional, relational and organizational identification valuable, finding the correlation used Spearman Correlation Test. Spearman Correlation Test results are shown in Table VIII.

TABLE VIII: THE RESUltS OF SPEARMAN CORRELATION TEST OF VALUABLES

\begin{tabular}{|l|l|c|c|c|}
\hline \multicolumn{1}{|c|}{ Dimensions } & \multicolumn{1}{|c|}{ Dimension } & $\mathrm{N}$ & $\mathrm{r}$ & $\mathrm{P}$ \\
\hline Transactional & Relational & 123 &, 222 &, 013 \\
\hline Transactional & Organizational Identification & 123 & -064 &, 480 \\
\hline Relational & Organizational Identification & 123 &, 171 &, 059 \\
\hline
\end{tabular}

Between transactional, relational and organizational identification variables made Spearman results of correlation analysis to determine the relationship, between relational variables and operational significantly positive at the level of $22.2 \%(p=, 013<.05)$ a very weak correlation, $6 \%$ in the organizational identification variable 4 level in the negative direction is very weak non-significant $(p=, 480>, 05)$ has been a very weak relationship. According to a very weak positive points relational variables of transactional variables, the higher the score, the score is very weak organizational identification variable is increasing in a negative direction.

Relationship with the Spearman results of correlation analysis conducted to determine the relationship between organizational identification variables, relationship between organizational identification variable is not significant in the positive direction at the level of $17.1 \%(p=, 059>, 05)$ has been a very weak relationship. Accordingly, the points score increases organizational identification of relational variables variable shows a positive increase as too weak.

\section{DISCUSSION AND CONCLUSIONS}

Changing perspectives of employees in organizations with the information age show that it is important to employees organizational citizenship behavior and keep them in organization because of if they leave the organization, they will take their organizational culture and knowledge together, they can give what organization want in term. Organizations understand that employees important for innovation and created added value, and also organizations spend money to keep these knowledge and skills. Therefore organizations should meet the expectations of employees, work colleagues, including creating the atmosphere of confidence and trust should be the top.

Administrators should know that psychological contract and to address more fully the expectation functions to organizational identification, otherwise the negative consequences of knowing may occur, the origin is and always personal perception a ware that vary and from one person to the expectations of these verity and vary the belief that met that need to know. Because of that to fulfill what put forth in job interview and when employees work period, if it cannot be in real, must be explain because of why. The analysis results in a negative correlation between organizational identification and transactional dimensions of the psychological contract of public employees, has been shown to have a positive relationship with relational. Akyüz (2014) study that reached similar conclusions have done your research. Conducting studies for the development of interrelations of public employees in organizational development will allow the organizational identification.

The relationship between gender and the psychological contract seems to be higher in men than in women transactional and relational level is examined. There is no significant relation between gender and organizational identification. The study of Bekaroğlu (2007), Alp (2015) [13] and Akyüz (2014) there is no significant relation between gender and psychological contract. In another study of Özdemir (2007), Fındık (2011), Akyüz (2014) and Barutçu (2015) [14] there is no significant differences between gender and organizational identification. These results support our research.

A significant difference was observed on the relationship between age and organizational identification. Significant differences of governmental employees in the 36-40 age range is due to lower levels of organizational identification. Age between transactional and relational variables were not significantly correlated. Bekaroğlu (2007), Özdemir (2007), Findık (2011) and Barutçu (2015) identification of organizational age in the work they have done, they concluded that there was no significant difference between transactional and relational variables. In the study of Polat (2009), Akyüz (2014) and Alp (2015) reached the conclusion that there is a significant difference between organizational identification age variable. These results are similar to results of your research. Between marital statuses, transactional, relational and organizational identification was found that there was no significant difference in terms. Alp (2015) study that reached similar conclusions have done your research.

A significant difference was seen when examining the relationship between and educational status to relational, transactional, organizational identification. Transactional variable significant differences in high school and graduate education with the participants, relational variable of the participants in the case of high school education are seen to arise from the participants at the undergraduate level in the organizational identification variable. Mimaroglu (2008) has made similar study results showed that psychological contract related, Demirkasimoglu (2012), Akyuz (2014) and Barutcu (2015) have done their work reached a different conclusion in.

Between operating time with transactional relationship, relational and organizational identification was found that there was no significant difference in terms. Barutcu (2015) and Alp (2015), the work they have done your research has reached similar conclusions. Psychological contract and organizational identification will provide employees to positive impact on increasing the efficiency and 
effectiveness. There are many studies in the literature that the psychological contract and organizational identification shall positively affect employees. Mimaroglu (2008) as a result of his work, employees who feel that a violation of the psychological contract has reached alow of the organizational commitment. Turker (2010) have made the working chute, ensure organizational commitment of those who work for organizations, will take place largely concluded by understanding their psychological contracts. Tukelturk and others (2012) have made a study that the fulfillment of the promises in the psychological contract by the employer, the employee has reached the conclusion that the ethical implications of increasing their commitment to the organization.

Bulut (2015) [15], on his work has concluded that positively influences the performance of organizational identification on employees. Alp (2015) on the work, concluded that there is a positive relationship between organizational citizenship behavior and organizational identification. Uray (2014) on his study, concluded that there is a direct impact on organizational identification of organizational trust. Organizational identification levels by putting more emphasis on the relational level of active

developers of public employees should be increased. The psychological contract studies, personal development, initiative-taking skills and problem solving investigations in to the context of what forms such as the order can be search in the future researches.

\section{REFERENCES}

[1] N. E. Akyüz, "The Relationship between psychological contract and organizational identification: The case of Ankara Ptt administration," Ph. D. Thesis, Dept. Business, Aksaray Univ., Aksaray, Turkey, 2014.

[2] N. Ö. İyigun and C. Cetin, "A study on the effect of organizational psychological contract deviation and pharmaceutical industry," Marmara University Social Science Instute Journal, vol. 10, p. 16, July 2012.

[3] M. D. Şahin, "Psikolojik Sözleșme," in Örgütsel Davranışta Güncel Konular, D. E. Özler, Eds., Ekin Press, 2012, ch. 5, p. 84.

[4] H. Mimaroglu, "Effects of psychological contract on personnel attitudes and behaviors: A study on medical sales people," Ph.D. Thesis, Dept. Business, Cukurova Univ., Adana, Turkey, 2008.

[5] H. A. Patrick, "Psychological contract and employment relationship," The ICFAI Journal of Organizational Behavior, vol. 7, p. 6, Apr. 2008.

[6] J. C. Shapiro and I. Kessler, "Consequences of the psychological contract for the employment relationship: A large scale survey," The Journal of Management Studies, vol. 37, p. 911, Dec. 2000.

[7] D. M. Rousseau, "Psychological contracts in the workplace: Understanding the ties that motivate," Academy of Management Executive, vol. 18, p. 123, July 2014.

[8] E. Turker, "Psychological contract relationship between organizational commitment: A case study on health care workers," M.S. Thesis, Dept. Business, Erzurum Atatürk Univ., Erzurum, Turkey, 2010.

[9] M. K. Topcu, "Effect of psychological contract on the relationship between personality and intent-to-quit and organizational identification of employees," Ph.D. Thesis, Dept. Defence Management, Turkish Military Academy, Ankara, Turkey, 2015.
[10] M. Uray, "Customer orientation, organizational trust, organizational commitment, organizational identification," Ph.D. Thesis, Dept. Business, Marmara Univ., Istanbul, Turkey, 2014.

[11] R. Altunışık, R. Coşkun, S. Bayraktaroğlu, and E. Yıldırım, Sosyal Bilimlerde Araş̧tırma Yöntemleri, Sakarya, Turkey, 2012, pp. 139141.

[12] Ş. Kalaycı, SPSS Uygulamalı Çok Değiş̧kenli İstatistiksel Teknikleri, Istanbul, Turkey, 2010, p. 405.

[13] A. G. Alp, "Organizational identification of health care workers, organizational citizenship and differences between perceptions of organizational conflict communication: (A Field Study)," M.S. Thesis, Dept. Business, Business, Beykent Univ., Istanbul, Turkey, 2015.

[14] K. Barutcu, "A research to determinate the relation between perceived organizational support and organizational commitment and organizational identification levels at The Public Sector," M.S. Thesis, Dept. Business, Eskisehir Osmangazi Univ., Eskisehir, Turkey, 2015.

[15] E. Bulut, "The relation between personnel empowerment, organizational identification and employee performance: Research participation banks," M.S. Thesis, Dept. Business, Business, Beykent Univ., Istanbul, Turkey, 2015.

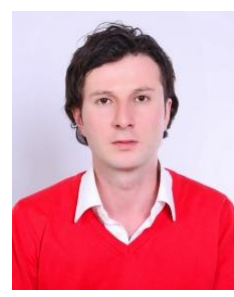

Ayhan Bayram was born in Giresun on April 10, 1987. He got a bachelor's degree of the business management at Karadeniz Technical University (Trabzon, 2004-2008). He is graduated from master program which about Management and Organization Department at Trakya University (Edirne, 2009-2012), he is a postgraduate of the Management and Organization Department at Trakya University (Edirne, 2012-2015). His research interests include crises management, human research, reputation management, time, management, strategic management, etc.

Dr. Bayram was a worked officer at Istanbul Metropolitan Municipality. He is a working doctor of Business Management Department at the Halic University. His reports are: "Female and male students on personal development initiative for self-editing investigation of takıng skills the effects," International Refereed Journal of Humanities and Academic Sciences, Istanbul, Turkey, 2015. The Sports: Malmö-Sweeden, $20^{\text {th }}$ Annual Congress of the European. "The relationship between the personal growth initiative and self-handicapping of teachers physical education and sports," Malmö-Sweeden, $20^{\text {th }}$ Annual Congress of the European College of Sport Science Sustainable Sport, 2015. "The effect the total quality management and employee satisfaction of urban transportation the Istanbul example," Istanbul-Turkey, $8^{\text {th }}$ International Transportation Technology Symposium and Fair, 2015.

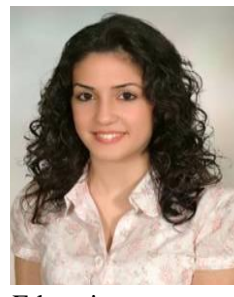

Ece Zeybek was born in Istanbul on November 14, 1985. She is a lecturer of Tourism and Hospitality Department at the Istanbul Arel University. She is also a postgraduate of the Management and Organization Department at Marrmara University Business Faculty. She graduated from master program which about Tourism Management Education in Gazi University (Ankara, 2007-2010) and Department of Hospitality Management

Education

Ms. Zeybek was worked in different chain hotels. Her research interests include tourism business education, human research, information systems management, knowledge management, customer relationship management, strategic management etc. and her reports are: "The effects of transactional and transformational leadership on employee turnover in the dimension of employeea: A research on hospitality businesses in Istanbul" (KonyaTurkey, 1st Europe Tourism Congress, May, 2015), "A model for generating and sharing information about cultural assets," (Hawai-USA, 016 Hawaii Global Conference on Business and Finance). 